\title{
Desalination study of physicochemical properties from soils in mechanic workshops within Okitipupa, Ondo state, Nigeria.
}

\author{
Adebayo Alaba Joseph ${ }^{1}$, IlemobayoIfedayo Oguntimehin ${ }^{1}$, Labunmi Lajide ${ }^{2}$ and Jayeoye J Titilope ${ }^{3 *}$ \\ ${ }^{1}$ Department of Chemical Sciences, Ondo State University of Science and Technology, Okitipupa, Ondo- State \\ ${ }^{2}$ Department of Chemistry, Federal University of Technology, Akure, Ondo-State \\ ${ }^{3}$ Department of Chemistry, Federal University Ndufu Alike Ikwo, Ebonyi State, Nigeria
}

\begin{abstract}
Auto Mechanic Workshops in thestudy area generate waste containing hazardous chemicals Thirty-six Soil samples were collected from selected automobile workshops (five) in the study area at the depths of 0-15 cm, 30-45 cm, $45-60 \mathrm{~cm}, 60-75 \mathrm{~cm}$ and $75-100 \mathrm{~cm}$. A total of sixty (30) soil samples were collected in five different locations in the ancient town of Okitipupa. Six control samples were also collected in a farm land about $3 \mathrm{~km}$ away from Auto Mechanic Activities. The physicochemical parameters such as soil composition based on particle size in percentage, ranged 7.65-10.71 for clay, 1.93-6.99 for silt and 85.36-89.98 for sand $\mathrm{pH}$ values ranged 4.57-5.93 and electrical conductivity $(\mathrm{EC})\left(\mathrm{uscm}^{-1}\right)$ ranged 31.67- 143.67. The percentage soil composition was in this order; Sand $>$ Clay $>$ Silt. Assessment of $\mathrm{pH}$ shows acidity increases down the depth of the profile and EC follows the same trend. Comparing the values with the control indicate the presence of soluble inorganic salts that is higher in the study area than control.
\end{abstract}

Keywords: Soils, pH, electrical conductivity, particle size and automobile workshops.

Accepted on August 02, 2017

\section{Introduction}

Okitipupa, Ondo- State, Nigeria is a Town with Water and Land Transportation Systems. It is the single largest industrial cluster of artisians in Ikale land. These artisian activities contribute to waste generation in the environment which includes metal scraps, used batteries, packaging materials, spent lubricants and worn-out parts, which contain contaminants such as heavy metals [1,2]. Artisan activities in most mechanic workshops are not properly monitored and regulated; these activities give rise to elevated levels of metals and hydrocarbons in the environment. Soils may contain large amounts of heavy metals and hydrocarbons with varying concentration ranges depending on anthropogenic and natural activities occurring or once occurred and the surrounding geological environment.

Heavy metals contaminate the soil from different sources and show different behaviour in soil [3]. According to [4], the ability of soil to immobilse introduced chemicals like heavy metals depends on sorption properties of the soil (soil texture, $\mathrm{pH}$, moisture content and cation exchange capacity). Metals on the surface of the soil may be carried by runoff water and transported to the groundwater [5].

Literature search revealed that only few studies have been conducted on the level of soil pollution by auto-mechanic waste in Nigeria such as the study conducted in Iwo [6], Port Harcourt [7], Akure [8] and in the Imo river basin [9], We're not up to the depth of $100 \mathrm{~cm}$ and no such work has been done in the study area. Hence, this study was conducted as there is a need for evidence from studies in more cities so that a more definitive conclusion can be made on the level of soil pollution by automechanic waste in Nigeria.

\section{Materials and Methods}

\section{The study area}

The study area is Okitipupa, Ondo-State, Nigeria (Figure 1). It is a Town with Water and Land Transportation Systems. It is situated between $6^{\circ} 30^{\prime} 0^{\prime \prime}$ North, $4^{\circ} 48^{\prime} 0^{\prime \prime}$ East. It has an area of $803 \mathrm{~km}^{2}$ and a population of 233,565 at the 2006 census. It is the single largest industrial cluster of artisans in Ikale land. Figure 1 is the map of Okitipupa showing the sampling points.

\section{Soil sampling}

A total of sixty (30) composite soil samples were collected from ten (5) selected automobile workshops within Okitipupa using standard soil auger, at the depths of $0-15 \mathrm{~cm}, 15-30 \mathrm{~cm}, 30-45$ $\mathrm{cm}, 45-60 \mathrm{~cm}, 60-75 \mathrm{~cm}$ and $75-100 \mathrm{~cm}$ representing six samples per location, respectively. Soil samples were collected at random from the five different locations at each automobile shop which were then mixed up to obtain a composite soil sample at each soil depth separately. The soil samples were placed in polythene bags and transported to the laboratory. The location and elevation of each selected site was recorded with a global positioning system (GPS). The control samples were collected from the Ondo State University of Science and Technology (OSUSTECH), Farmland about $3 \mathrm{~km}$ away from the point of impact where there are neither car repairs nor commercial activities, with no drainage influence and no likelihood of from used motor oil.

\section{Soil sample treatment and analysis}

Soil samples were air-dried at room temperature for 1 week to avoid microbial degradation. The samples were homogenized and gently crushed repeatedly using a mortar and pestle, and passed through a $0.125 \mathrm{~mm}$ sieve prior to analysis. 


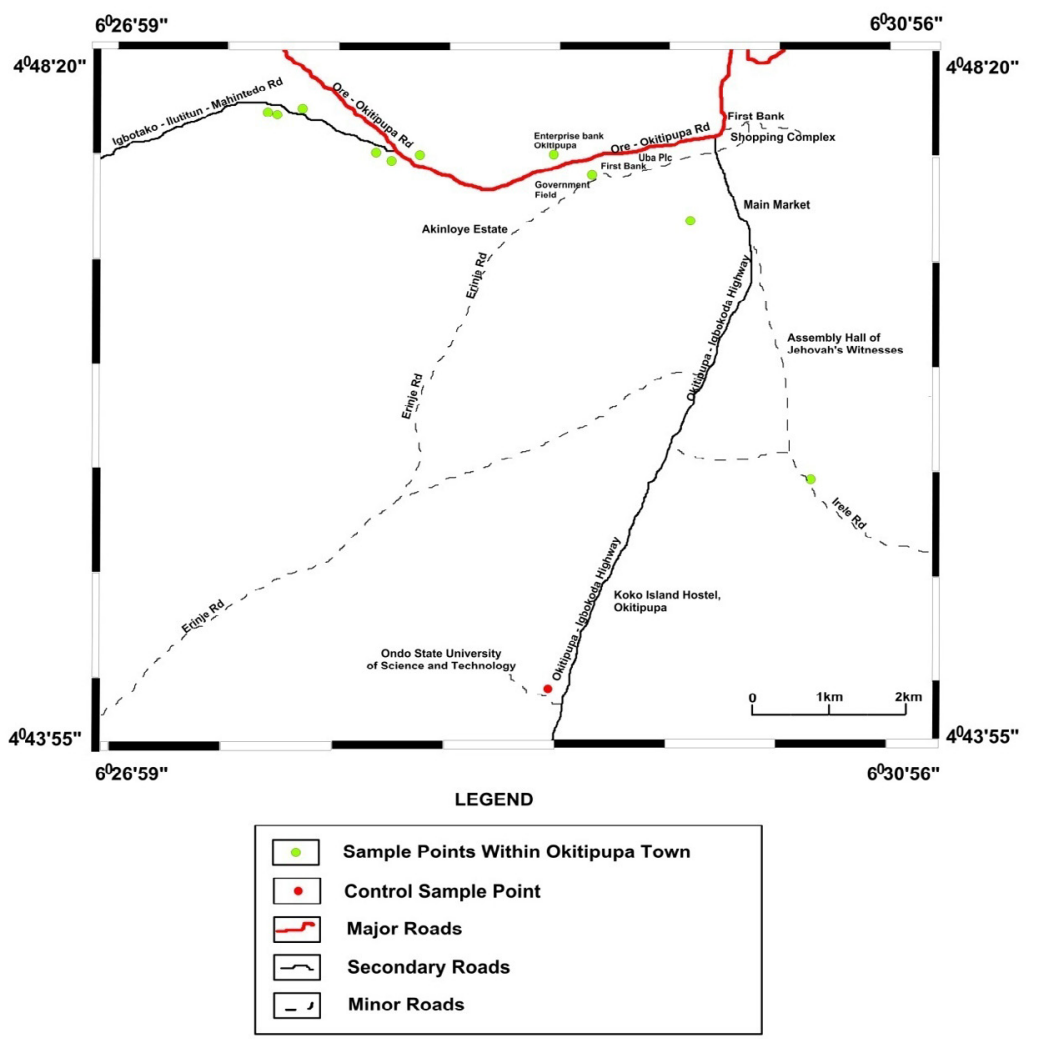

Figure 1. Map of Okitipupa showing the sampling points.

\section{Analysis of samples}

\section{Determination of physico-chemical parameters}

pH: A soil-water suspension was prepared using a soil to water ratio of 1:2. The contents were allowed to equilibrate for 30 minutes and the $\mathrm{pH}$ was recorded with the aid of a calibrated Uniscope model PHS- 3B pH meter. The $\mathrm{pH}$ meter was initially calibrated by placing the $\mathrm{pH}$ electrode into a buffer solution of known $\mathrm{pH}(\mathrm{pH} 4.2),(\mathrm{pH} 7)$ and $(\mathrm{pH} \mathrm{10)}$. The instrument was adjusted until the meter read the known $\mathrm{pH}$ value of the buffer solution. With the $\mathrm{pH}$ meter calibrated, the electrode was then rinsed three times with distilled water. The electrode was placed in the soil water suspension, allowed to stabilize and the $\mathrm{pH}$ value was taken from the instrument. Triplicate $\mathrm{pH}$ values were taken.

Electrical Conductivity: The conductivity of the soil samples were determined using Labtech digital electrical conductivity meter. The instrument was initially calibrated by rinsing with $0.01 \mathrm{M}$ potassium chloride $(\mathrm{KCl})$ solution. The conductivity of this standard is known to be $1413 \mu \mathrm{S} / \mathrm{cm}$; the electrode was rinsed with distilled water and then immersed in a soil: water suspension $(1: 2)$ for the actual reading. Triplicate values were taken.

Particle size analysis- Hydrometer method: $51 \mathrm{~g}$ air dry soil sample was weighed into a $250 \mathrm{ml}$ beaker; $100 \mathrm{ml}$ of 50 $\mathrm{g}$ of calgon per liter of distilled water (a solution of sodium hexametaphosphate, $\left.\mathrm{Na}\left(\mathrm{PO}_{3}\right)_{6}\right)$ was added and allowed to soak for at least 30 minutes. The suspension was stirred vigorously for 1 minute using a glass rod. The suspension was transferred into a mixer with baffled cups and mixedfor 15 minutes at a medium speed. The suspension were transferred into a $1 \mathrm{~L}$ sediment cylinder and made up to the mark with deionised water. The hydrometer was placed into the suspension until it floated. The plunger was inserted into the sediment cylinder, the content was properly agitated with strong upward strokes of the plunger and the initial hydrometer reading $(\mathrm{H} 1)$ was taken after 40 seconds. The hydrometer was removed and the initial temperature $\left(\mathrm{T}_{1}\right.$ in $\left.{ }^{\circ} \mathrm{C}\right)$ of the suspension was measured with a thermometer. The final hydrometer $\left(\mathrm{H}_{2}\right)$ and temperature $\left(\mathrm{T}_{2}\right.$ in ${ }^{\circ} \mathrm{C}$ ) readings were measured after the suspension was left to stand for 2 hours. The readings were taking in triplicates for reliability of the results. The respective percentages were calculated according to equations 2-4.

$$
\begin{aligned}
& (\% \text { Silt }+\% \text { Clay })=\frac{T 1+(H 1 \times 0.36) \times 100}{51} \\
& \% \text { Clay }=\frac{T 2+(H 2 \times 0.36) \times 1000}{51} \\
& \% \text { Sand }+\% \text { Silt }+\% \text { Clay }=100 \% \\
& \% \text { Silt }=(\% \text { Silt }+\% \text { Clay })-\% \text { Clay } \\
& \% \text { Sand }=100-(\% \text { Clay }+\% \text { Silt })
\end{aligned}
$$

Where $\mathrm{H} 1=$ hydrometer reading after 40 seconds

$\mathrm{T} 1=$ temperature after 40 seconds

$\mathrm{H} 2=$ hydrometer reading at 2 hours

$\mathrm{T} 2=$ temperature reading at $2 \mathrm{hours}$

Add $0.36 \mathrm{~g} / \mathrm{L}$ for every $1^{\circ} \mathrm{C}$ above $20^{\circ} \mathrm{C}$ and subtract $0.36 \mathrm{~g} / \mathrm{L}$ for every $1^{\circ} \mathrm{C}$ below $20^{\circ} \mathrm{C}=$ temperature correction to be added to the hydrometer reading [10]. 


\section{Statistical analysis}

Statistical analysis is very useful in providing knowledge and assisting in the interpretation of data. It is widely applied in recent times to investigate the heavy metal concentration, accumulation and the distribution in soils [11]. Statistical analyses of heavy metal contents in soil samples from Automechanic Workshops in Okitipupa were performed using one way anova to estimate the mean value, standard deviation, standard error and Pearson's correlation analysis by the software package SPSS version 16.0.

\section{Results and discussion}

Soil physicochemical properties: Table 1 presents the results of the percentage soil compositions based on particle size of soil from Sites A-E and Control. Also Table 2 presents Mean Values of Physicochemical Properties of Soils from Sites A-E and Control.

Soil pH: The $\mathrm{pH}$ values of the soil samples in all the sites ranged from 4.09 to 5.94. This shows that the soils were moderately acidic. The values decreased with depth indicating that the acidity of the soils increased with depth. The $\mathrm{pH}$ values obtained in this study are in the same range with the values reported by [12-14], but lower than those reported by [1517]. Soil $\mathrm{pH}$ and other soil properties are especially important in soil processes responsible for solubility of heavy metals in soil and their transportation [18-22]. The equilibrium between metal speciation, solubility, adsorption and exchange on solid phase sites is intimately connected to solution $\mathrm{pH}[18-20,15]$. Hence, numerous studies have found soil $\mathrm{pH}$ to have a large effect on metal bioavailability [21,22]. At high $\mathrm{pH}$, metals tend to form metal mineral phosphates and carbonates which are insoluble while at low $\mathrm{pH}$ they tend to be found as free ionic species or as soluble organometals and are more bioavailable [12-14]. Since at low pH (acidic) metals are more soluble and more bioavailable in the soil solution, the range of $\mathrm{pH}$ values obtained in this study will favour plant uptake of heavy metal and hence toxicity problems are possible. Figure 2 below shows $\mathrm{pH}$ distribution in all the sites.
Electrical conductivity (EC): The electrical conductivity (EC) of the soil samples from all the sites ranged from $(\mu \mathrm{Scm}-1) 31.00$ to 143.67 . The range of values obtained in this study is higher than that reported by $[12,14]$ but lower than the values reported by $[23,24,17]$. These values indicate significant presence of trace metal ions or ionisable materials in the soil $[25,14]$. According to Rhoades JD [26], soils with conductivities values $>150 \mathrm{uS} / \mathrm{cm}$ are highly saline. The soil samples in all the sites recorded conductivities values in the range $31.00-143.67 \mu \mathrm{S} / \mathrm{cm}$ as indicated in Table 2 and Figure 3.

Analysis of the soil samples from the different sites revealed that conductivities of soil samples are higher as compared to control which ranges from $20.00-46.00 \mu \mathrm{S} / \mathrm{cm}$. This finding is in-line with the study done by [27] for automobile dumpsites at Agbor and Abraka in Nigeria. The oldest site $\mathrm{C}$ recorded the highest electrical conductivity as shown in Table 2 and Figure 3. This result is in line with those obtained by [8] from automobile workshops in Akure, Nigeria.

Particle Size: For particle size distribution, sand size fraction was highest, followed by clay and then silt as shown on Figures 4-6 below and Table 1 above. These proportions show that the soils were coarse and as such have low supply of nutrients and moisture unlike fine textured soils that have sufficient water holding capacity, good aeration and high supply of nutrients [28]. The soils have low sorption capacity for ions due to their sandy texture. The amount of retained in the soil depends not only on the metal concentration and redox state of the metal but also the soil type and texture. Soil texture plays an important role in the mobility of heavy metals in the soil. Soils with high clays/ fine content can retain significant amount of the metal contaminant while sandy soils will enhance the transport of the contaminants. Clays and hydrous oxides, i.e. oxides of $\mathrm{Al}, \mathrm{Fe}$ and $\mathrm{Mn}$, play an important role in the availability of metals. Clays and hydrous oxides determine metal availability mainly by specific adsorption to surface hydroxyl groups [29,30], nonspecific adsorption (exchange) [31], co precipitation [32],

Table 1. Mean Percentage composition of soil in soils from sites a-e and control.

\begin{tabular}{|c|c|c|c|c|c|c|c|c|c|c|c|c|c|c|c|c|c|c|}
\hline \multirow{2}{*}{$\operatorname{Depth}(\mathrm{m})$} & \multicolumn{3}{|c|}{ A } & \multicolumn{3}{|c|}{ B } & \multicolumn{3}{|c|}{ C } & \multicolumn{3}{|c|}{ D } & \multicolumn{3}{|c|}{$E$} & \multicolumn{3}{|c|}{ Control } \\
\hline & $\% \mathrm{Cl}$ & $\% \mathrm{Si}$ & $\% \mathrm{Sa}$ & $\% \mathrm{Cl}$ & $\% \mathrm{Si}$ & \%Sa & $\% \mathrm{Cl}$ & $\% \mathrm{Si}$ & $\% \mathrm{Sa}$ & $\% \mathrm{Cl}$ & $\% \mathrm{Si}$ & $\% \mathrm{Sa}$ & $\% \mathrm{Cl}$ & $\% \mathbf{S i}$ & \%Sa & $\% \mathrm{Cl}$ & $\% \mathrm{Si}$ & $\% \mathrm{Sa}$ \\
\hline 0.15 & 9.53 & 1.93 & 88.54 & 9.29 & 2.76 & 88 & 8.59 & 3.43 & 89.98 & 8.35 & 2.59 & 89.1 & 7.88 & 3.7 & 88.4 & 9.06 & 3.79 & 87.2 \\
\hline 0.3 & 9.29 & 2.63 & 88.08 & 8.59 & 2.76 & 88.7 & 8.59 & 3.73 & 87.68 & 10.7 & 2.29 & 87 & 7.65 & 3.8 & 88.6 & 9.06 & 3.89 & 87.1 \\
\hline 0.45 & 9.29 & 2.66 & 88.04 & 8.35 & 3.46 & 88.2 & 9.06 & 5.21 & 85.73 & 10 & 2.49 & 87.5 & 7.88 & 3.13 & 89 & 9.06 & 3.76 & 87.2 \\
\hline 0.6 & 9.29 & 2.39 & 88.31 & 8.59 & 2.69 & 88.7 & 9.09 & 5.48 & 85.46 & 8.35 & 3.36 & 88.3 & 7.65 & 3.33 & 89 & 8.59 & 4.06 & 87.4 \\
\hline 0.75 & 9.29 & 2.39 & 88.31 & 8.59 & 3.23 & 88.2 & 8.35 & 5.55 & 86.1 & 9.76 & 3.03 & 87.2 & 7.88 & 4.09 & 88 & 8.59 & 4.8 & 86.6 \\
\hline 1 & 9.29 & 2.6 & 88.11 & 7.88 & 4.44 & 87.7 & 7.65 & 6.99 & 85.36 & 9.29 & 3.4 & 87.3 & 7.65 & 4.46 & 87.9 & 8.59 & 4.73 & 86.7 \\
\hline
\end{tabular}

NOTE: $\% \mathrm{Cl}=\%$ Clay, $\% \mathrm{Si}=\%$ Silt, $\% \mathrm{Sa}=\%$ Sand

Table 2. Mean Values of physiochemical properties of soils from sites a-e and control.

\begin{tabular}{|c|c|c|c|c|c|c|c|c|c|c|c|c|c|c|c|c|c|c|}
\hline \multirow[b]{2}{*}{ Depth(m) } & \multicolumn{3}{|c|}{ A } & \multicolumn{3}{|c|}{ B } & \multicolumn{3}{|c|}{ C } & \multicolumn{3}{|c|}{ D } & \multicolumn{3}{|c|}{$E$} & \multicolumn{3}{|c|}{ Control } \\
\hline & $\mathrm{pH}$ & $\begin{array}{l}\text { Temp } \\
\left({ }^{\circ} \mathrm{C}\right)\end{array}$ & $\begin{array}{c}E C \\
\left.\text { (uscm }^{-1}\right)\end{array}$ & $\mathrm{pH}$ & $\begin{array}{l}\text { Temp } \\
\text { ('C) }\end{array}$ & $\begin{array}{c}E C \\
\left(u s^{s c^{-1}}\right)\end{array}$ & $\mathrm{pH}$ & $\begin{array}{l}\text { Temp } \\
\left({ }^{\circ} \mathrm{C}\right)\end{array}$ & $\begin{array}{c}\text { EC } \\
(\text { (uscm } \\
\text { (1) }\end{array}$ & $\mathrm{pH}$ & $\begin{array}{l}\text { Temp } \\
\text { ('C) }\end{array}$ & $\begin{array}{c}\text { EC } \\
(\text { (uscm } \\
\text { (1) }\end{array}$ & $\mathrm{pH}$ & $\begin{array}{c}\text { Temp } \\
\text { ('C) }\end{array}$ & $\begin{array}{c}\text { EC } \\
\left(\text { usscm }{ }^{-1}\right)\end{array}$ & pH & $\begin{array}{l}\text { Temp } \\
\left({ }^{\circ} \mathrm{C}\right)\end{array}$ & $\begin{array}{c}E C \\
\left(u \mathbf{s c m}^{-1}\right)\end{array}$ \\
\hline 0.15 & 5.76 & 24.6 & 61.33 & 4.77 & 25.4 & 70.3 & 5.75 & 25.5 & 60 & 5.25 & 25.8 & 44.3 & 5.07 & 26.1 & 90.7 & 4.95 & 26.7 & 46 \\
\hline 0.3 & 5.77 & 24.7 & 109.6 & 4.86 & 25.5 & 50.3 & 5.74 & 25 & 60 & 5.14 & 25.5 & 31.7 & 5.19 & 26.2 & 60.7 & 4.94 & 26.8 & 40 \\
\hline 0.45 & 5.93 & 25.1 & 80.33 & 4.74 & 25.7 & 70.3 & 5.65 & 25.8 & 136 & 4.94 & 25.6 & 38.3 & 5.37 & 25.7 & 55 & 4.85 & 26.7 & 37 \\
\hline 0.6 & 5.82 & 25.1 & 54.67 & 4.64 & 25.7 & 69.7 & 5.83 & 25.8 & 144 & 4.84 & 26.1 & 52.7 & 5.14 & 25.6 & 53 & 4.98 & 26.8 & 31 \\
\hline 0.75 & 5.72 & 25.1 & 75.67 & 4.7 & 25.9 & 7.33 & 5.63 & 25.9 & 118 & 4.6 & 25.8 & 44.7 & 5.15 & 26.6 & 46 & 5.05 & 26.8 & 20 \\
\hline 1 & 5.64 & 25 & 80.33 & 4.57 & 25.7 & 58.7 & 5.43 & 25.9 & 117 & 5.55 & 25.9 & 54.7 & 5.11 & 26.4 & 41 & 5.02 & 26.7 & 26.3 \\
\hline
\end{tabular}




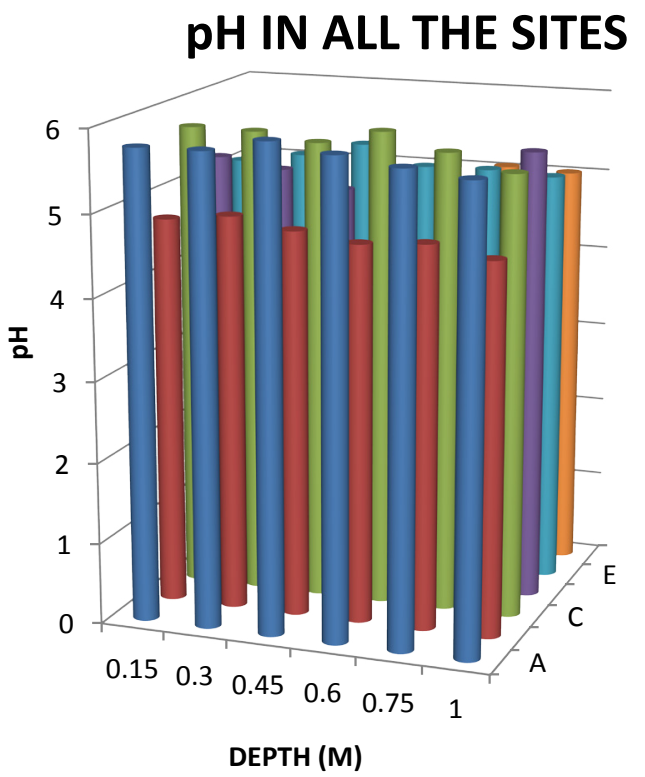

$\mathrm{A}$
$\mathrm{B}$
$\mathrm{C}$
$\mathrm{D}$
$\mathrm{E}$
CONTROL

Figure 2. $p H$ distribution in all the sites.

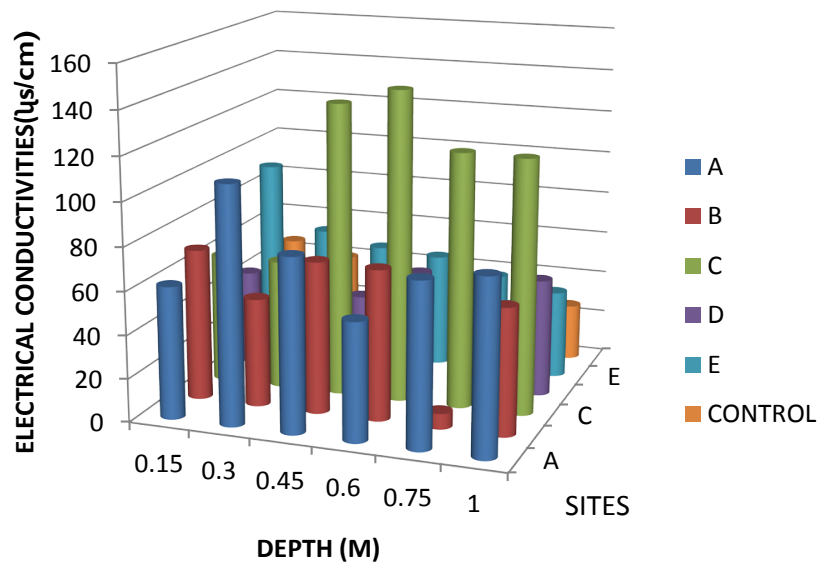

Figure 3. Electrical conductivity in all the sites.

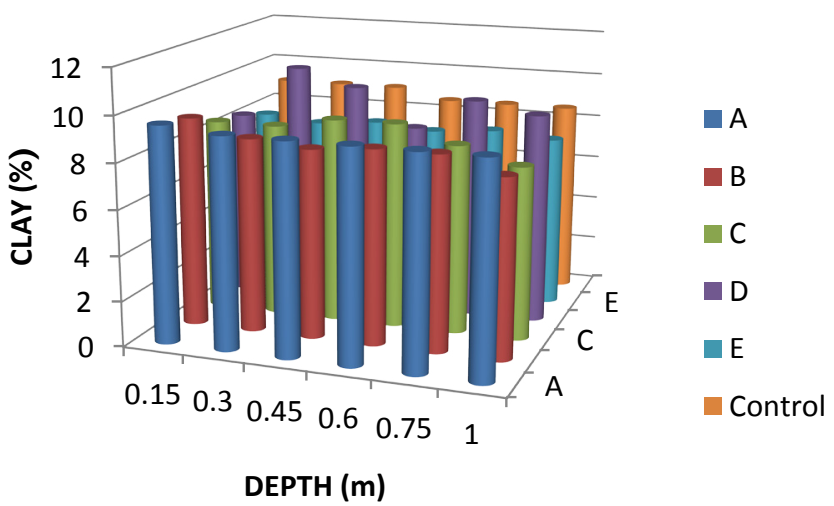

Figure 4. Percentage clay composition in all the sites.

and precipitation as the discrete metal oxide or hydroxide [32] Hence, increasing clay and hydrous oxide contents in soils provides more sites for adsorption of metals thus reducing the directly bio available metal [33-35]. From the results, it can be inferred that adsorption of heavy metals on the soils due to artisans' activities in Okitipupa may be low and the

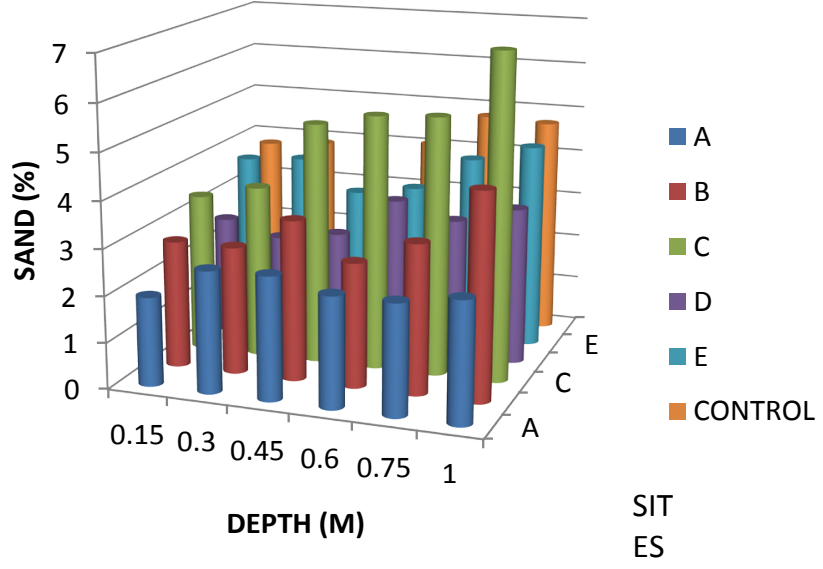

Figure 5. Percentage composition of silt in all the sites.

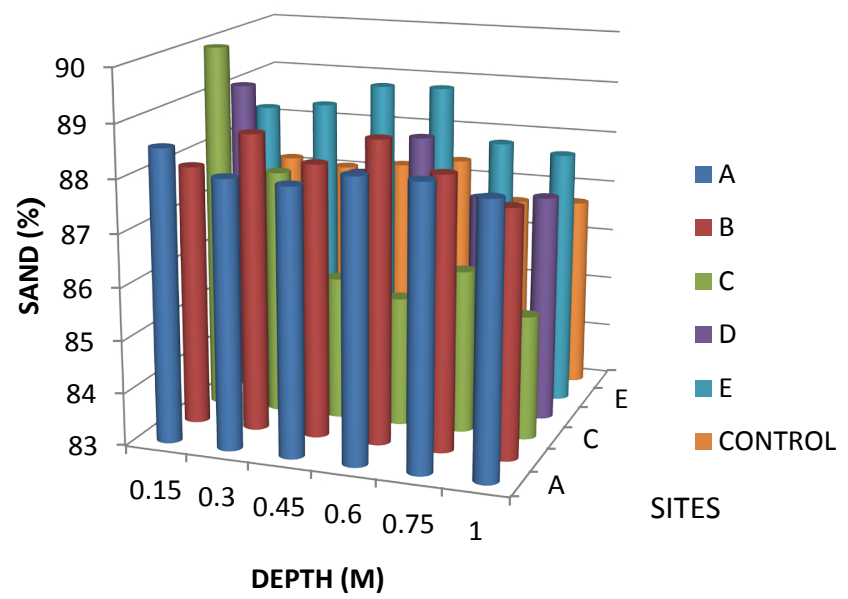

Figure 6. Percentage composition of sand in all the sites.

transport of these metals are likely to occur. Figures 4-6 below represents percentage soil compositions for Clay, Silt and Sand respectively.

Temperature: Temperature has been found to be positively correlated with plant uptake of $\mathrm{Pb}$ and $\mathrm{Cd}$ [33-36]. This relationship has been attributed to decreasing rates of organic matter decomposition at lower temperatures reducing mobilisation of organo-metal complexes [30]. In contrast, Kalbasi $\mathrm{M}$ did not observe any effect of temperature on $\mathrm{Pb}$ solubility [31]. Basta NT noted that variations in temperature had no measurable effect on the leaching of $\mathrm{Cd}$ [32]. The temperature are general the same in each site but varies in all the sites as show in Figure 7 above.

\section{Conclusion and recommendation}

The acidity and the conductivity values of the soils in almost all the soil samples from the various sites increased with depth. The particle size distribution for soils at the different depth in all the five sites contain a higher percentage of sand followed by clay and silt. This work reveals that $\mathrm{pH}$, percentage soil composition and temperature are major factors that may be responsible for solutes nobilities in the soil profile, while electrical conductivities may indicates the level of contamination or pollution of a site with dissolved ions [37]. 


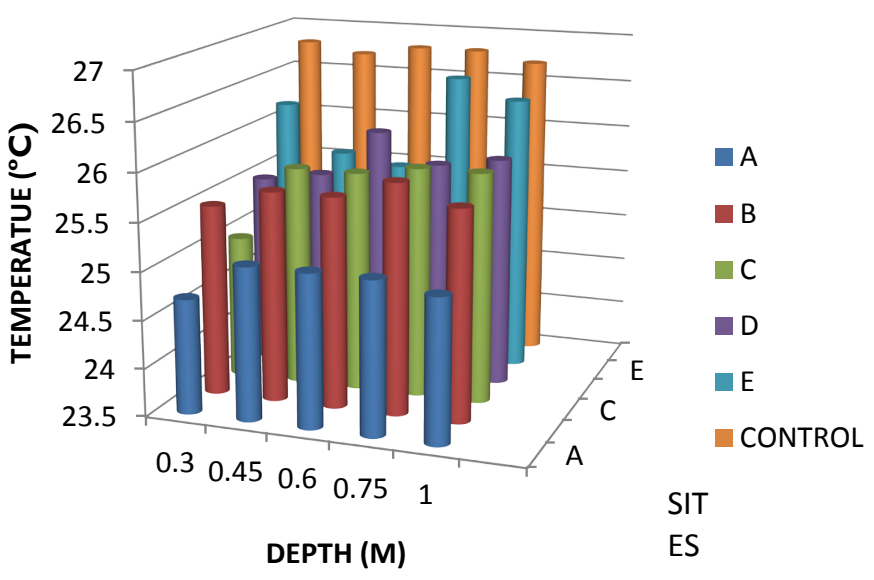

Figure 7. Temperature distribution in all the sites.

Further works on speciation of the metals should be carried out in order to ascertain the form in which the various metals exist since it may have effect on its mobility in the soil. Modern waste disposal facilities should be acquired by relevant authorities and appropriate waste disposal sites be chosen to avoid the injurious effects of indiscriminate disposal of wastes. Study of different remediation schemes to ascertain the most effective approach to remove metals from the soil and stabilize soil $\mathrm{pH}$ for agricultural practices. Re-refining techniques for used engine oil should be employed in order to preserve our environment. Similar Work Should be done during the dry Season.

\section{References}

1. Pam AA, Sha'Ato R, Offem OJ. Contributions of Automobile Mechanic Sites to Heavy Metals in Soil: A Case Study of North Bank Mechanic Village Makurdi, Benue State, Central Nigeria. Journal of Chemical, Biological and Physical Sciences. 2013;3(3):2337-47.

2. Pam AA, Sha'Ato R, Offem OJ. Evaluation of heavy metals in soils around automechanic workshop clusters in Gboko and Makurdi, Central Nigeria. Journal of Environmental Chemistry and Ecotoxicology. 2013;5(11):298-306.

3. Soltan ME, Fawzy EM, Rashed MN. Assessment on the degree of immobilization of heavy metals in contaminated urban Soils by selected phosphate rocks of different particle sizes. Malaysian Journal of soil science. 2012;16:103-20.

4. Dube A, Zbytniewski R, Kowalkowski T, et al. Adsorption and Migration of Heavy Metals in Soil. Polish Journal of Environmental Studies. 2001;10(1);1-10.

5. Wuana RA, Okieimen FE. Heavy metals in contaminated soils: A review of sources, chemistry, risks and best available strategies for remediation. International Scholarly Research Notices. 2011:1-20.

6. Ipeaiyeda AR, Dawodu M. Heavy metals contamination of topsoil and dispersion in the vicinities of reclaimed autorepair workshops in Iwo, Nigeria. Bull Chem Soc Ethiopia. 2008;22(3):339-48.

7. Iwegbue CM. Metal fractionation in soil profiles at automobile Mechanic Waste Dumps around Port Harcourt. Waste Manage Res. 2007;25(6):585-93.
8. Oguntimehin I, Ipinmoroti K. Profile of Heavy Metals from Automobile Workshops in Akure Nigeria. Journal of Environmental Science and Technology. 2008;1(1):19-26.

9. Nwachukwu MA, Feng H, Alinnor J. Assessment of Heavy Metals Pollution inSoils and their Implications within and Around Mechanic Villages. Int J Environ Sci tech. 2010;7(2):347-58.

10. Ibitoye AA. Laboratory Manual on Basic Soil Analysis $2^{\text {nd }}$ ed, 82pp Foladare Publishing company Akure, Ondo State Nigeria. 2006.

11. Qishlaqi A, Moore F. Statistical analysis of accumulation and sources of heavy metals occurrence in agricultural soils of Khoshk River Banks, Shiraz, Iran. American-Eurasian Journal of Agriculture and Environmental Science. 2007;2(5):565-73.

12. Osakwe SA. Assessment of the effects of wood processing industries in selected parts of Delta State, Nigeria on the soils and vegetation in their vicinities. IOSR Journal of Applied Chemistry. 2013;3:22-30.

13. Osakwe SA. Heavy metal contamination and physicochemical characteristics of soils from automobile workshops in Abraka, Delta State, Nigeria. International Journal of Natural Science Research. 2014;2(4):48-58.

14. Egbenda PO, Thullah F, kamara, I. A physicochemical analysis of soil and selected fruits in one rehabilitated mined out site in the Sierra Rutile environs for the presence of heavy metals: Lead, Copper, Zinc, Chromium and Arsenic. African Journal of Pure and Applied chemistry. 2015;9(2):27-32.

15. Cavallaro N, McBride MB. Zinc and copper sorption and fixation by an acid soil clay: Effect of selective dissolutions. Soil Science Society of America Journal. 1984;48:1050-54.

16. Matthews-Amune OC, Kakulu S. Investigation of heavy metal levels in road-side agricultural soil and plant samples in Adogo, Nigeria. Academic Journal of Environmental Sciences. 2013;1(2):31-5.

17. Idugboe SO, Tawari-Fufeyin P, Midonu AA. Soil pollution in two auto mechanic villages in Benin city, Nigeria. IOSR Journal of Environmental Science Toxicology and Food Technology. 2014;8:9-14.

18. Olomu MO, Racz GJ, Cho CM. Effect of flooding on the Eh, $\mathrm{pH}$, and concentrations of Fe and $\mathrm{Mn}$ in several Manitoba soils. Soil Science Society of America Proceedings. 1973;37:220-24.

19. Kalbasi M, Racz GJ, Loewen Rudgers LA. Mechanism of zinc adsorption by iron and aluminum oxides. Soil Science. 1978;125:146-50.

20. Sauve S, McBride MB, Norvell WA, et al. Copper solubility and speciation of in situ contaminated soils: effects of copper level, $\mathrm{pH}$ and organic matter. Water, Air and Soil Pollution. 1997;100:133-49. 
21. Turner AP. The responses of plants to heavy metals. In Toxic Metals in Soil-Plant Systems, Ross SM, editor. John Wiley and Sons, Chichester; 1994. pp.153-87.

22. McBride M, Sauve S, Hendershot W. Solubility control of $\mathrm{Cu}, \mathrm{Zn}, \mathrm{Cd}$ and $\mathrm{Pb}$ in contaminated soils. European Journal of Soil Science. 1997;48:337-46.

23. Obasi NA, Akubugwo OC, Ugbogu OC, et al. Assessment of physicochemical properties and heavy metals availability in dumpsites along Enugu Port Harcourt expressways, South East Nigeria. Asian Journal of applied Sciences. 2013;5:342-56.

24. Badejo AA, Taiwo AO, Adekunle AA, et al. Spatiotemporal levels of essential trace metals around municipal solid waste dumpsite sin Abeokuta, Nigeria. Pacific Journal of Science and Technology. 2013;14(2):682-92.

25. Fuller MA, Feamebough W, Mitchel D, et al. Desert reclamation using yellow river irrigation water in Ningxia, china. Soil use and Management. 1995;11:77-83.

26. Rhoades JD. Cation exchange capacity. In: AL Page (editor) Methods of soil analysis. Part 2: Chemical and microbiological properties (2nd edition.). Agronomy. 1982. p. 149-57.

27. Akpovata OV, Osakwe SA, Okoh BE, et al. Physicochemical characteristics and levels of some heavy metals in soils around metal scrap dumps in some parts of Delta State, Nigeria. Journal of Applied Sciences and Environmental Management. 2010;14(4):57-60.

28. Wilde SA, Weight GK, Ixer JG. Soil and Plant Analysis for the Culture. New Delhi, Oxford B.H. Publication Company. 172-1143. 1972.
29. Miller WP, Martens DC, Zelazny LW. Short-term transformations of copper in copper-amended soils. Journal of Environmental Quality. 1987;16:176-80.

30. Pampura TB, Pinskiy DL, Ostroumov VG, et al. Experimental study of the buffer capacity of a Chernozem contaminated with copper and zinc. Eurasian Soil Science. $1993 ; 25: 27-38$.

31. Kalbasi M, Racz GJ, Loewen Rudgers LA. Mechanism of zinc adsorption by iron and aluminum oxides. Soil Science. 1978;125:146-50.

32. Basta NT, Tabatabai MA. Effect of cropping systems on adsorption of metals by soils: II. Effect of $\mathrm{pH}$. Soil Science. 1992;153:195-204.

33. Martinez CE, McBride M. Solubility of $\mathrm{Cd}^{2+}, \mathrm{Cu}^{2+}, \mathrm{Pb}^{2+}$ and $\mathrm{Zn}^{2+}$ in aged coprecipitates with amorphous iron oxides. Environmental Science and Technology. 1998;32:743-48.

34. Shuman LM. The effect of soil properties on zinc adsorption by soils. Soil Science Society of America Proceedings. 1975;39:454-58.

35. Ghanem SA, Mikkelsen DS. Sorption of zinc on iron hydrous oxide. Soil Science. 1988;146:15-21.

36. Barrow NJ. Mechanisms of reaction of zinc with soil and soil components. In 'Zinc in Soil and Plants' (ed. Robson AD). Kluwer Academic Publishers, Dordrecht. 1993. pp. 15-31.

37. Miller WP, Martens DC, Zelazny LW. Short-term transformations of copper in copper-amended soils. Journal of Environmental Quality. 1987;16:176-80.

\section{*Correspondence to:}

Jayeoye J Titilope

Department of Chemistry

Ebonyi State

Nigeria

Tel: +66641425482

E-mail: titilope12@gmail.com 